\title{
Efficient hybridization procedure for better pod setting in inter-specific crosses involving vigna species
}

\begin{abstract}
Vigna species being rich in protein plays an important role in diets of people, particularly in Asia. Among the several Vigna species, V. radiata (mung bean) and V. mungo (urdbean) are the important food legumes and grown throughout the year (Kharif, Rabi and summer seasons) in India. Being a short duration crop, mungbean and urdbean appear to be a better option as it may be well fitted in rice-wheat cropping system without compromising the area of other crops. However, the available cultivars of mungbean and urdbean are plagued with a number of biotic and abiotic factors. Hence, there is a need to look for alien Vigna species to diversify and broaden the genetic base of cultivated germplasm of these species. V. umbellata (rice bean), a potential source for resistance to biotic stresses as well as several other yield traits can be used as a donor parent. However, differential amount of success of inter specific hybridization varying from low to very low have been observed. To obtain successful hybrids, high percentage of pod setting during crossing is one of the prerequisites. Keeping the above backdrops into consideration, an efficient hybridization procedure is proposed in this review to achieve maximum success in inter specific hybridization in Vigna species.
\end{abstract}

Keywords: Vigna, mungbean, urdbean, rice bean, inter specific hybridization
Volume 8 Issue 2 - 2018

\author{
A Nishant Bhanu, MN Singh, K Srivastava \\ Department of Genetics and Plant Breeding, Institute of \\ Agricultural Sciences, Banaras Hindu University, India
}

Correspondence: Nishant Bhanu, Department of Genetics and Plant Breeding, Institute of Agricultural Sciences, Banaras Hindu University, Varanasi - 221005, India,

Email nishant.bhanu@gmail.com

Received: December 30, 2017 | Published: March 05, 2018

\section{Introduction}

Food legumes are next to cereals in terms of their economic and nutritional importance as human food and play an important role in maintaining soil fertility by atmospheric nitrogen fixation through symbiosis with Rhizobium species, and also in sustainability of production systems. In recent times, main concern has been on increasing the production of pulses to curtail protein malnutrition, rising imports, and make pulses reasonable to the common man. The demand for food legumes has doubled in the last quarter century. Legumes or pulses belong to family, Leguminosae also known as Fabaceae or Papilionaceae and these terms can be used interchangeably. ${ }^{1}$ The Leguminosae family is classified into three subfamilies: Papilionoideae, Caesalpinioideae, and Mimosoideae. N. I. Vavilov created the morphology chart of domesticated papilionaceous legumes. The four main genera of grain legumes are Phaseolus, Vicia, Vigna, and Glycine. The generic epithet Vigna was named after the Botanist, Dominico Vigna. The genus Vigna is a large pantropical genus with 82 species distributed among seven subgenera. ${ }^{2}$ phylogenetically; Vigna has close relation with agriculturally important genera Cajanus, Glycine, and Phaseolus. In the genus Vigna, only subgenus Ceratotropis has its centre of species diversity in Asia. Among the cultivated species of Vigna in Asia, only V. radiata (mung bean), is a mandate crop of an international centre (AVRDC, Taiwan, China) which supports the crop improvement activities. However, with the advent of genetic resource analysis and genome mapping in the last two decades, significant scientific advances for the Asian Vigna have become possible. ${ }^{3,4}$ Among the several pulses grown, mung bean and urdbean are the important food legumes and grown throughout the year (Kharif, Rabi and summer seasons) in India.

\section{Production constraints}

For enhancing the production of pulses at national level, mungbean and urdbean, being a short duration crop, appear to be a better option as it may be well fitted in rice-wheat cropping system without compromising the area of other crops. However, the available cultivars of mungbean and urdbean are plagued with a number of biotic and a biotic factor ultimately, reducing the yield considerably. Among prevalent diseases, though Mung bean Yellow Mosaic Virus (MYMV), Cercospora Leaf Spot (CLS) and Powdery Mildew (PM) are the most common, the MYMV causes drastic reduction in yield in all the crop seasons.

Among the various diseases limiting mungbean and urdbean productivity, yellow mosaic virus (YMV), a member of family Geminiviridae belonging to Begomovirus genus is the most destructive and widely distributed, causing $10-100 \%$ yield losses depending on the crop stage at which the plants are infected. ${ }^{5}$ The virus is transmitted by whitefly vector, Bemisia tabaci and shares a very narrow host range within legumes (Cajanus cajan, Vigna mungo, Vigna radiata and Glycine max). Disease symptoms after virus infection depend on the host species and susceptibility of each plant. Disease symptoms vary from a few small yellow specks or spots on a 
few leaves, to yellowing or chlorosis of all leaves of the whole plant followed by necrosis. In highly susceptible plants, symptoms includes shortening of internodes, severe stunting of plants with few flowers or even no yield as deformed pods produces small, immature and shriveled seeds. Management of this disease is only possible by the way of reducing the whitefly population using insecticides which are ineffective under severe infestations and thus limiting this complete destruction of virus. Therefore, development and use of virus resistant cultivars turns out to be the most reasonable and economical strategy for controlling the disease ${ }^{6}$ Cercospora Leaf Spot (CLS), caused by the biotropic fungus Cercospora canescens and Cercospora cruenta affects the production in South East Asia. The fungus initially causes spotting on mungbean leaves which increases in number and size during flowering, but the increment is most rapid at the pod-filling stage, being usually observed in the month of September-October in eastern part of India. In susceptible varieties, infection expands rapidly resulting in premature defoliation and reduction in size of pods and seeds, ${ }^{7}$ causing an yield loss varying from $23 \%$ to maximum of $61 \%{ }^{8}$ Though, few donor for resistant to CLS are reported, they are not usually stable over years and locations. ${ }^{9}$

Powdery mildew caused by Erysiphe polygoni D.C. is the most devastating fungal disease of rabi mungbean in South-East Asia ${ }^{10} \mathrm{As}$ well as late kharif sown crop in Northern part of the country. The powdery mildew disease usually appears on 35-40 days old crop, ${ }^{11}$ during flowering and pod formation stage. ${ }^{12}$ The fungus attacks all parts of the plant except roots. The initial symptoms are faint, slightly dark areas developing over the leaf, later turning into small, white powdery spots. These spots enlarge, coalesce and develop into a complete coating by a white to dirty-white powdery growth consisting of mycelium and conidia. In epidemic form, the fungus covers all parts of the plant with white powdery growth, thereby adversely affecting the photosynthetic activity of the plant. Consequently, defoliation takes place and pods are not formed and if formed they bear subnormal seeds, ${ }^{13}$ Which in turn, reducing the yield as well as market price, causing enormous economic loss to the farmers. The yield losses due to this disease in mungbean are reported to be 20 $40 \%{ }^{14}$ and even $100 \%$, when the disease occurs at the seedling stage. ${ }^{15}$ The basic reason for limited success had been due to the limited variability prevailed among the mungbean and urdbean parents used for hybridization in most of the studies. Extensive screening of the germplasm collections of these species under field and controlled conditions has not yielded any robust source of resistance to these pathogens. Induced mutagenesis using in-vivo and in-vitro techniques has also been ineffective in the induction of resistance. Resistance towards the yellow mosaic disease, CLS is more common in V. mungo as compared to V. radiata but the resistance breaks down frequently due to rapid formation of new pathotypes. ${ }^{16}$

\section{Inter-specific hybridization and pre-breeding}

There is no other alternative but to look for alien Vigna species to diversify and broaden the genetic base of cultivated germplasm. Rice bean, a potential source for resistance towards MYMV as well as several other yield traits can be used as a donor parent. Introgression of alien genes from wild species would not only minimize the risks of biotic and abiotic stresses but will also make discernible quality and yield advances in the crop. Therefore, pre-breeding practices are urgently required involving particularly those cultivated/wild species that carry useful genes for improving yield, quality, biotic and abiotic stress resistance. To isolate rare recombinants having high yield potential coupled with high degree of resistance to prevalent diseases, it is necessary to have information regarding the cross ability among the diverse parents. The success of breeding programmes mainly depends upon the choice of superior parents for hybridization and clear-cut understanding of genetic system involved in the inheritance of the yield traits. There had been always possibility of improving the crop by incorporating wild genes to the cultivated species.

Stepwise utilization of primary, secondary and tertiary gene pools of this crop can result in tremendous improvement in yield. For utilizing the variability available in the secondary and tertiary gene pools, it is essential to attempt inter-specific crosses and to develop viable hybrids. The introgressed materials developed through wide crosses will increase the available gene pool by contributing as genetic reservoirs for novel genes apart from contributing to the improvement of yield and yield components. However, incompatibility between these species hampers the transfer of desired genes and limits the potential for improving the productivity. Mungbean has certain desirable characters, viz., erect growth habit, large number of seeds pod $^{-1}$, early maturity and desired quality traits. On the other hand, urdbean has certain other desirable characters such as dwarf plant types with good branching, synchronous maturity, non-shattering pods and durable resistance to CLS. ${ }^{17}$ However, rice bean possesses several useful characters like number of clusters plant ${ }^{-1}$ bearing long pods with large number of bold seeds pod ${ }^{-1}$ coupled with more durable resistance to MYMV, CLS, powdery mildew and bruchids.

\section{Brief description of three Vigna species}

\section{Mungbean [Vigna radiata (L.) Wilczek]}

Mungbean also known as mung/moong, green gram, golden gram, Chichsaw pea and Oregonpea ${ }^{18}$ belong to the tribe Phaseolea of family Leguminosae and is an immensely important pulse crop of our country. The progenitor of mungbean is presumed to be Vigna radiata var. sublobata ${ }^{19}$ It is an annual erect or sub erect plant, sometimes slightly twining at the tips. The leaves are alternate, trifoliate, ovate and dark or light green. The inflorescence is an axillary raceme bearing yellow flowers and the keel is spirally coiled with a horn-like appendage. Pods are long, slender, containing 6-10 globose, round or elongated seeds which are mostly green but sometimes yellow, tawny brown, black or mottled in colour. The hilum is flat having epigeal germination. $^{20}$

\section{Urd bean [Vigna mungo (L.) Hepper]}

Urdbean also known as black gram, black lentil, mungbean, matpe bean, is a food legume belonging to the sub-genus Ceratotropis. The progenitor of urdbean is presumed to be Vigna silvestris. ${ }^{21}$ Urdbean is an important pulse crop and mainly grown in the states of Madhya Pradesh, Maharashtra, Uttar Pradesh, Rajasthan, Karnataka and Bihar. It is an annual herbaceous plant attaining a height of 30 to $100 \mathrm{~cm}$. Leaves are large, trifoliate hairy, and usually with a purplish tinge. The inflorescence consists of a cluster of five to six flowers at the top of a long hairy peduncle. The pods are long $(4-6 \mathrm{~cm})$ and cylindrical containing four to ten seeds. The seeds are generally black or dark brown. The split seed of urdbean is creamish white in colour and germination of seed is of epigeal type. ${ }^{22}$ 


\section{Rice bean [Vigna umbellata (Thunb.) Ohwi and Ohashi]}

Rice bean, a minor pulse crop, possess high yield potential coupled with stable resistance to prevalent diseases, may be considered as source of several desirable genes for the genetic improvement of other cultivated species. The progenitor of rice bean is thought to be Vigna umbellata var. gracilis. ${ }^{23}$ Rice bean mainly grown in northern India and Southeast Asia have fine freely branched stem with oval and trifoliate small leaves. The plant has usually indeterminate growth habit and inflorescences are 4-7 cm long with 10-18 bright yellow flowers, bearing long pods $(12-18 \mathrm{~cm})$ with $6-10$ seeds and highly resistance to bruchids, yellow mosaic virus, Cercospora leaf spot and bacterial leaf spot. ${ }^{24}$ It is also a rich source of limiting amino acids, methionine and tryptophan ${ }^{25}$ as well as valine, tyrosine and lysine, ${ }^{26}$ besides containing vitamins such as thiamine, riboflavin, niacin and ascorbic acid. ${ }^{27}$ It is tolerant to acid soils and adverse abiotic stress conditions. ${ }^{28,29}$ Catechin-7-O-glucoside is found in the seed of $V$. umbellata which has an antioxidant activity leading to a cytoprotective effect. ${ }^{30}$

\section{Crossability studies}

The inter-specific hybrids have been attempted by several workers ${ }^{31-37}$ and $F_{1} \mathrm{~S}$ were found to be sterile or partially fertile. The reasons for failure of inter-specific crosses in food legumes are not fully understood. In some cases, the pollen tubes are unable to penetrate the stigma and style, ${ }^{31}$ whereas in some cases, fertilization occurs, but embryo abortion takes place during embryogenesis. ${ }^{38-42}$ Among all the possible reasons, the failure of inter-specific hybridization due to embryo degeneration is common in inter-specific crosses of food legumes. Differential amount of success of inter-specific hybridization varying from low to very low has been observed and reported to be in the range of $22.5 \%$ to $2.3 \% \cdot{ }^{35,43}$ Numerous pre and post fertilization barriers account for poor success of crossings. The production of hybrids as well as the subsequent fertility of these hybrids is required for the transfer of alien genes by sexual means. To get successful hybrids, high percentage of pod setting during crossing is one of the prerequisites. Flowering and pod setting is affected by photoperiods, genetic response of the genotypes, rain fall, relative humidity, wind speed and temperature. ${ }^{44,45}$ Further, the high frequency of flower drop under artificial pollination makes crossing very tedious. ${ }^{46}$ The timings of Anthesis (between 05:00 to 08:00 a.m.), dehiscence of anthers (10 to 14 hours before Anthesis) and receptivity of the stigmas (from the time of anthesis up to 6 to 8 hours after Anthesis) are identical in these three Vigna species. However, the average length of style is slightly variable in the three species as it is $19 \mathrm{~mm}$ in $V$. umbellata, $21 \mathrm{~mm}$ in $V$. mungo and $23 \mathrm{~mm}$ in $V$. radiata.

\section{Crossing method}

The mungbean, urdbean and rice bean plant flowers in phases with axillary or terminal racemes containing a cluster of 10 to 20 cleistogamous flowers. Flower shedding is common, averaging about $60 \%$. Out crossing of 2 to $5 \%$ may take place ${ }^{47,48}$ Which varies with the cultivar and the season. Based on the previous studies, ${ }^{46,49,50}$ the following hybridization procedure is proposed to achieve maximum success in inter specific hybridization in Vigna species:

1) Mungbean should be used as seed parent to make successful inter-specific crosses with urdbean and rice bean. Likewise, urdbean should be taken as female parent in inter-specific crosses with rice bean. In reciprocal crosses, either pod abscises in early stage or if developed, it contains in viable seeds.

2) Buds of optimum size having light green colour should be selected and emasculated in the evening before flower opening (4:00 to $6: 00$ p.m.).

3) For emasculation, open only the upper half of the standard, wing and keel petals with the help of dissecting needle or a forceps (Forceps No. 5) to expose the stigma and anthers and then remove the anthers carefully with the help of forceps. This method increases the success of pollination/fertilization as there are fewer disturbances on style and ovary in the bud during emasculation.

4) Pollination should be done in the next morning (5:00 a.m. to 7.00 a.m.). However, the time of pollination affecting crossing is directly related to weather conditions. Thus, the most optimum time for pollination during summer is $5: 30$ to $6: 30$ a.m. and during Kharif, it is 6:00-7:00 a.m. It has been observed that the chances of success decrease if the pollination is done after the sun shines completely.

5) For pollination, remove the wing and keel of the selected bud which is about to open over the stigma of the emasculated bud and gently rub the stigma containing dehisced anthers over the feathery part of the stigma of the emasculated bud for achieving maximum success.

6) To avoid any severe load, a total of 8-12 flowers per plant per day should be emasculated besides picking the self-pollinated flowers/pods.

It has been observed that an average of $22-23^{\circ} \mathrm{C}$ of lower temperature followed by lower relative humidity (45.0-55.0) during evening at the time of emasculation and comparatively enhanced sunshine ( $>8.5$ hours) favours the better pod setting for both intra and inter specific crosses. Lower relative humidity is more conducive for longevity of the buds/ young flowers and hence better pod setting for inter specific crosses. Consequently, late Kharif season, i.e., first fortnight of October to first fortnight of November is the most appropriate time for achieving maximum pod setting under natural field conditions. However, during pod setting in November, excessive dew may cause pod dropping. However, to minimise the pod dropping, it could be better to either cover the crossing block at least 7-8 feet above the ground level with plastic sheet or crossing can be done in the playhouse or glasshouse under controlled weather conditions. In the crossing block, urdbean should be sown five days earlier than mungbean and rice bean genotypes need to be sown 20-25 days earlier than urdbean for coinciding the flowering of the above three species. Thus, mungbean and urdbean should be planted in the second fortnight of August whereas, rice bean in the second fortnight of July. The material may also be planted in crossing block at two different dates with an interval of 07-10 days so that the duration of crossing programme could be prolonged. Using the above mentioned procedure of crossing, successful hybrids can be developed utilizing donors exhibiting a high level of resistance against MYMV, CLS etc.

\section{Acknowledgment}

None. 


\section{Conflict of interest}

None.

\section{References}

1. Morris B. Legumes. Solomon H Katz (editors). Encyclopaedia of Food and Culture. Charles Scribner \& Sons. 2003; New York, USA.

2. Maréchal R, Mascherpa JM, Stainier F. Combinaisons et noms nouveaux dans les genres Phaseolus, Minkelersia, Macroptilium, Ramirezella et Vigna. Taxon. 1978;27(2-3):199-202.

3. Tomooka N, Kaga A, Vaughan DA. The Asian Vigna (Vigna subgenus Ceratotropis) biodiversity and evolution. Plant Genome: Biodivers Evol. 2006;1(Part C):87-126.

4. Kaga A, Isemura T, Tomooka N, et al. The genetics of domestication of the adzuki bean (Vigna angularis). Genetics. 2008;178(2):1013-1036.

5. Nene YL. A survey of viral diseases of pulse crops in Uttar Pradesh. The University:India;1972.pp.191.

6. Karthikeyan A, Sudha M, Senthil N, et al. Screening and identification of RAPD markers linked to MYMV resistance in mungbean (Vigna radiata (L) Wilczek). Archives of Phytopathology and Plant Protection. 2012;45(6):712-716

7. Grewel JS, Machendra P, Kulshrestha DP. Control of Cercospora Leaf Spot of greengram by spraying Bavistin. Indian J Agric Sci. 1980;50(9):707-711.

8. Iqbal SM, Ghafoor A, Bashir M, Malik BA Estimation of losses in yield components of mug bean due to Cersospora leaf spot. Pakistan J Phytopathol. 1995;7:80-1.

9. Chupp C. A monograph of the fungus genes Cercospora, Cornell University,1953; Ithaca.

10. Park HG, Yang CN. The mungbean breeding programme at the Asian Vegetable Research and Development Centre. First Intl. Symp. Proc. Univ. Philippines. 1978;pp.214-21.

11. Khare N, Lankpale N, Agarwal KC. Epidemiology of powdery mildew of mungbean in Chattisgarh region of Madhya Pradesh. J Mycol Pl Path.1998;28:5-10.

12. Arjunan G, Vidyasekharan P, Kolandaisawmy S. How to combat disease of greengram. Farmer and Parliament. 1976;12:17-18.

13. Singh DP. Inheritance of resistance to yellow mosaic virus in blackgram [Vigna mungo (L.) Hepper]. Theor Appl Genet. 1980;57(5):233-235.

14. Fernandez GCJ, Shanmugasundaram S. The AVRDC mungbean improvement program: the past, present and future. In: McLean BT (eds.) Mungbean: proceeding of the second international symposium. Asian Vegetable Research and Development Center: Taiwan; 1988;pp.58-70.

15. Reddy KS, Pawar SE, Bhatia CR. Inheritance of powdery mildew (Erysiphe polygon D. C.) resistance in mung [Vigna radiata (L.) Wilczek]. Theor Appl Genet. 1994;88(8):945-948.

16. Karthikeyan A, Sudha M, Pandiyan M, et al. Screening of MYMV resistant mungbean (Vigna radiata (L.) Wilczek) progenies through agroinoculation. Int J Plant Pathol. 2011;2(3):115-125.

17. Singh DP. Distant hybridization in genus Vigna: A review. Indian Journal of Genetics and Plant Breeding. 1990;50(3):268-276.

18. Chatterjee D, Randhawa GS. Standardized names of cultivated plants in India-II. Cereals, pulses, vegetables and spices. Indian J Hort. 1952;9:64-84.
19. Tomooka N, Vaughan DA, Moss H, et al. Introduction. In: The Asian Vigna. Springer. 2002; Netherlands; pp.1-7.

20. Bailey LH. Manual of Cultivated Plants. MacMillan: New York; 1970 pp.1116.

21. Lukaki L, Maréchal R, Otoul E. The wild ancestors of the cultivated beans Vigna radiata (L.) Wilczek and V. mungo (L.) Hepper. Bull du Jardin Botanique de Belgique. 1980;50(3-4):385-391.

22. Jansen PCM (2006) Vigna mungo (L.) Hepper. Record from Protabase. Brink M and Belay G, editors. PROTA (Plant Resources of Tropical Africa/Ressources végétales de l'Afrique tropicale), Wageningen, Netherlands.

23. Tomooka N, Lairungreang C, Nakeeraks , et al. Mungbean and the genetic resources, the Subgenus Ceratotropis. Trop Agri Res Center Tsukuba. 1991; Japan.

24. Saikia P, Sarkar CR, Borua I. Chemical composition, antinutritional factors and effect of cooking on nutritional quality of ricebean [Vigna umbellata (Thunb; Ohwi and Ohashi)]. Food Chem. 1999;67(4):347352 .

25. De Carvalho, NM, Vieira RD. Rice bean (Vigna umbellata (Thunb.) Ohwi et Ohashi). In: Food and feed from legumes and oilseeds. Springer. 1996; pp. 222-228.

26. Mohan VR, Janardhanan K. Chemical composition and nutritional evaluation of raw seeds of six rice bean varieties. J Indian Bot Soc. 1994;73(3-4):259-263

27. Joshi KD, Bhandari B, Gautam R, editors. Ricebean: a multipurpose underutilized legume. Paper presented at $5^{\text {th }}$ International Symposium on New Crops and Uses: Their roles in a rapidly changing world. Organized by the Centre for Underutilized Crops, University of Southampton in partnership with National Non-food Crops Centre and the Tropical Agricultural Association, 2006; England.

28. Dwivedi GK (1996) Tolerance of some crops to soil acidity and response to liming. J Indian Soc Soil Sci. 44(4):736-741.

29. Kashiwaba K, Tomooka N, Kaga A, et al. Characterization of resistance to three bruchid species (Callosobruchus spp., Coleoptera, Bruchidae) in cultivated ricebean (Vigna umbellata). J Econ Entomol. 2003;96(1):207213.

30. Baek JA, Son YO, Fang M, et al. Catechin-7-O- $\beta$-d-glucopyranoside scavenges free radicals and protects human $\beta$ lymphoma BJAB cells on $\mathrm{H}_{2} \mathrm{O}_{2}$-mediated oxidative stress. Food Science and Biotechnology. 2011;20(1):151-158.

31. Chowdhury RK, Chowdhury JB. Intergeneric hybridization between Vigna mungo (L.) Hepper and Phaseolus calcaratus Roxb. Indian J Agril Sci. 1977;47:117-121.

32. Subramanian D. Inter-specific hybridization in Vigna. Indian J Genet. 1980;40(2):437-438

33. Shanmungam AS, Rathnasamy R, Rangasamy SRS. Crossability studies between greengram and blackgram. Curr Sci. 1983;52(1):1018-1020.

34. Singh MN, Singh RM. Observation on the inter-specific hybrids between two species of Vigna. In Abs: Golden Jubilee Nat Symp New Delhi. 1991;pp.708-709.

35. Singh MN, Kumar R, Singh RM, Singh UP. Inter-specific hybridization between mungbean and urdbean. Indian J Pulse Res.1997;10(2):237239.

36. Singh MN, Singh SK. Study of induced amphidiploid derivatives of Vigna $\times$ Vigna mungo. Indian J Genet Plant Breed. 2006;66(30):245246 
37. Bhanu AN, Kumar P, Singh MN, et al. Assessment of genetic purity of inter-specific $\mathrm{F}_{1}$ hybrids involving Vigna radiata and Vigna umbellata. J Exp Bio Agril Sci. 2017a;5(5):636-643.

38. Honma S. A bean inter-specific hybrid. J Hered. 1956;47(5):217-220.

39. Al-Yasiri SA, Coyne DP. Inter-specific hybridization in the genus Phaseolus. Crop Sci. 1966;6(1): 59-60.

40. Ahn CS, Hartman RW. Inter-specific hybridization among four species of the genus Vigna. In: Proc First Intl Mungbean Symp Asian Vegetable Res. and Develop Centre, Shanghua, Taiwan,1977;240-246.

41. Ahn CS, Hartman RW. Inter-specific hybridization between mungbean [Vigna radiata (L.) Wilczek] and adzuki bean (Vigna angularis (wild) Ohwi and Ohashi). J Am Soc Hortic Sci. 1978a;103:3-6.

42. Ahn CS, Hartman RW. Inter-specific hybridization between ricebean (V. umbellata (Thumb) Ohwi and Ohashi) and adzuki bean (Vigna angularis (wild.) Ohwi and Ohashi). J Am Soc Hortic Sci. 1978b;103: 435-438.

43. Egawa Y. Phylogenetic differentiation between three Asian species, V. radiata, V. mungo and V. umbellata. Bull Natl Inst Agrobiol. Resour. 1988;4:189-200.
44. Talukdar A, Shivakumar M. Pollination without emasculation: an efficient method of hybridization in soybean [Glycine max (L.) Merrill]. Curr Sci. 2012;103:628-630.

45. Khattak GSS, Haq M, Ashraf M, et al. Genetic analysis of photoperiodsesitivity, flowering and maturity response in Mungbean (Vigna radiata (L.) Wilczek). J ISSAS. 2002;7:31-36.

46. Khattak GSS, Haq MA, Rana SA, et al. Efficient technique for crossing mungbean (Vigna radiata (L.) Wilczek). Thai J Agril Sci. 1998;31(4):577-582.

47. Van Rheenen HA. Preliminaty study of natural cross-fertilization in mungbean, Phaseolus aureus Rxob. Netherlands J Agric Sci. 1964;12:260-262.

48. Bhadra SK, Shill M. Natural out crossing in mungbean (Vigna radiata (L.) Wilczek). Bangladesh J Bot. 1986;15:217-220.

49. Boling M, Sander DA, Matlock RJ. Mungbean hybridization techniques. Agron J. 1961;53:54-55.

50. Bhanu AN, Singh MN, Srivastava K. Consequence of weather conditions for affecting cross ability in three Vigna species. Elec J Plant Breed. 2017b;8(2):7572-576. 